\title{
KORELASI USIA METABOLIK TERHADAP INDEKS MASSA TUBUH
}

\author{
Ni Nyoman Sri Yuliani ${ }^{1}$, Elsa Trinovita ${ }^{1}$ \\ ${ }^{1}$ Program Studi Pendidikan Dokter, Fakultas Kedokteran Universitas Palangka Raya, \\ Palangka Raya, Kalimantan Tengah, Indonesia \\ E-mail : nyomigiziklinik@gmail.com
}

\begin{abstract}
ABSTRAK
Akumulasi lemak berlebihan dalam tubuh menyebabkan peningkatan Indeks Massa Tubuh (IMT). Peningkatan IMT dan komorbiditas mempengaruhi laju metabolik tubuh. Usia metabolik dipengaruhi oleh laju metabolik individu. Tujuan penelitian ini adalah untuk mengetahui gambaran usia metabolik terhadap kenaikan IMT. Penelitian cross-sectional ini menggunakan metode purposive sampling sehingga diperoleh sebanyak 82 subyek laki-laki dan perempuan. Subjek dilakukan pengukuran IMT dan usia metabolik, kemudian data yang terkumpul dianalisis secara univariat dan bivariat korelasional. Hasil penelitian didapatkan adanya korelasi bermakna antara usia metabolik dengan IMT $(p=0,001)$ dengan $r=0,812$. Kesimpulan penelitian ini adalah peningkatan IMT, maka semakin tinggi usia metabolik.
\end{abstract}

Kata Kunci : Indeks Massa Tubuh, Usia Metabolik

\begin{abstract}
ABSTRAK
Excessive fat accumulation in the body causes an increase in Body Mass Index (BMI). Increased $\mathrm{BMI}$ and comorbidities affect the metabolic rate. Metabolic age was influenced by the individual metabolic rate. The purpose of this study was to determne the description of metabolic age to BMI increasement. This cross-sectional study used a purposive sampling method to obtain 82 male and female subjects. Subjects were measured for BMI and metabolic age. Collected data was analyzed univariately and bivariately correlatively. The result showed a significant correlation between metabolic age and BMI $(p=0,001)$ with $r=0,812$. The conclusion of this study is the increase in BMI, the higher the metabolic age.
\end{abstract}

Keywords : Body Mass Index, Metabolic Age 


\section{PENDAHULUAN}

Peningkatan berat badan pada manusia memiliki asosiasi dengan peningkatan jaringan lemak dalam tubuh sehingga menyebabkan obesitas [1]. Obesitas merupakan masalah kesehatan di negara maju dan negara berkembang [2], [3]. Masalah obesitas di Indonesia berdasarkan data Riset Kesehatan Dasar tahun 2018, mengalami peningkatan dibandingkan tahun 2007 [4]. Salah satu pengukuran antropometri sebagai indikator peningkatan berat badan adalah Indeks Massa Tubuh (IMT). Pengukuran IMT merupakan pengukuran sederhana dan paling sering digunakan untuk mengetahui kondisi lemak dalam tubuh [5]. Beberapa penelitian menemukan kaitan peningkatan IMT dengan peningkatan risiko komorbiditas seperti penyakit jantung, , hipertensi, dyslipidemia, diabetes mellitus tipe 2, batu empedu dan kanker [6]. Komorbiditas yang terjadi seiring dengan peningkatan berat badan akan mempengaruhi laju metabolik tubuh [7].

Laju metabolik atau sering disebut sebagai Basal Metabolic Rate (BMR) merupakan laju oksidasi jaringan terhadap sumber energi oleh semua organ tubuh. Pengukuran laju metabolik menggunakan alat direct calorimeter dan indirect calorimeter [8]. Terdapat banyak faktor yang mempengaruhi laju metabolic tubuh, yaitu usia, ukuran tubuh, status gizi dan hormon
[8]. Usia metabolik merupakan parameter yang membandingan BMR individu dengan rata-rata BMR berdasarkan kelompok usia kronologis [9]. Usia metabolik yang tinggi dibandingkan dengan usia kronologis mengindikasikan adanya perubahan laju metabolik [10]. Adanya indikasi perubahan laju metabolik ini menyebabkan usia metabolik dapat menjadi penanda kesehatan metabolik [11]. Berdasarkan keterkaitan IMT dengan peningkatan berat badan dan laju metabolik, maka penelitian ini ingin mengetahui gambaran hubungan IMT dengan usia metabolik, sehingga diharapkan IMT dapat menjadi pengukuran sederhana usia metabolik untuk menskrining risiko komorbiditas secara dini.

\section{METODOLOGI}

Penelitian ini menggunakan desain penelitian obsevasional secara crosssectional. Penelitian dilakukan di Universitas Palangka Raya dan wilayah kerja Puskesmas Pahandut Kota Palangka Raya, mulai bulan Mei hingga Juli 2019. Pengambilan sampel penelitian menggunakan metode purposive sampling sehingga diperoleh sebanyak 82 sampel.Sampel penelitian adalah dewasa laki-laki dan perempuan usia 30-59 tahun. 
Kriteria inklusi yaitu tidak menjalani program diet dan bersedia menjadi subyek penelitian. Subyek penelitian di eksklusi jika terdapat kecacatan mayor pada ekstremitas dan mengalami edema.

Pengukuran antropometri yang dilakukan berupa pemeriksaan IMT dengan menimbang berat badan dan tinggi badan. Pemeriksaan berat badan menggunakan timbangan digital dengan ketelitian 0,1 kg. Pemeriksaan tinggi badan menggunakan stadiometer. Interpretasi IMT berdasarkan kriteria Asia-Pasific population by the Western Pasific Regional Office of the World Health Organisation. IMT normal 18,5 - 22,9 $\mathrm{kg} / \mathrm{m}^{2}$, Overweight $23-24,9 \mathrm{~kg} / \mathrm{m}^{2}$, obesitas $\geq 25 \mathrm{~kg} / \mathrm{m}^{2}$. Pemeriksaan usia metabolik, menggunakan Bioelectrical Impedance Analyzer (BIA) Karada Scan HBF 701 pro (Japan).

Data karakteristik subyek penelitian dianalisis secara univariat. Data IMT dan usia metabolik di analisis secara bivariat korelasional menggunakan aplikasi SPSS (Statistical Package for the Social Sciences).

\section{HASIL DAN PEMBAHASAN}

Hasil penelitian ini didapatkan total subyek sebanyak 82 orang. Karakteristik subyek penelitian didominasi oleh subyek yang berusia $30-40$ tahun (50\%) dan jenis kelamin perempuan (71,9\%). Hasil pemeriksaan IMT didapatkan obesitas lebih banyak dibandingkan dengan IMT normal dan overweight.

Tabel 1. Karakteristik Subyek Penelitian

\begin{tabular}{lcc}
\hline \multicolumn{1}{c}{ Variabel } & Jumlah & Persentase \\
\hline Usia (tahun) & & \\
$30-40$ & 41 & 50 \\
$41-50$ & 18 & 21,9 \\
$51-57$ & 23 & 28,1 \\
Jenis Kelamin & & \\
- Laki-laki & 23 & 28,1 \\
- Perempuan & 59 & 71,9 \\
Indeks massa tubuh & & \\
(kg/m ${ }^{2}$ ) & 23 & 28,1 \\
- Normoweight & 5 & 6,1 \\
- Overweight & 54 & 65,8 \\
- Obesitas & & \\
\hline
\end{tabular}

Hasil uji korelasi Pearson pada tabel 2, didapatkan hubungan bermakna antara IMT dengan usia metabolic $(p<0,05)$. Nilai $r$ menunjukkan kekuatan korelasi yang kuat dengan arah korelasi positif yang berarti bahwa semakin besar IMT maka semakin tua usia metabolik.

Tabel 2. Korelasi Indeks Massa Tubuh dengan Usia Metabolik

\begin{tabular}{cccc}
\hline \multirow{2}{*}{$\begin{array}{c}\text { Indeks } \\
\text { Massa }\end{array}$} & \multicolumn{3}{c}{ Usia Metabolik } \\
\cline { 2 - 4 } Tubuh & $\mathbf{P}$ & $\mathbf{r}$ & $\begin{array}{c}\text { Arah } \\
\text { Korelasi }\end{array}$ \\
\cline { 2 - 4 } & 0,001 & 0,812 & $(+)$ \\
\hline
\end{tabular}




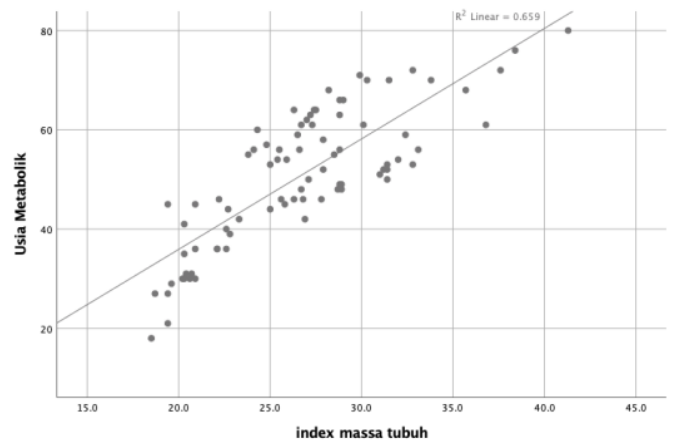

Gambar 1. Scatter Plot Hubungan IMT dengan Usia Metabolik

Berdasarkan hasil penelitian ini didapatkan bahwa terdapat hubungan bermakna antara kenaikan IMT dengan usia metabolik. Hasil penelitian ini sejalan dengan penelitian Refrensi [9] pada 90 subyek lakilaki dewasa, didapatkan bahwa terdapat korelasi bermakna antara usia metabolik dengan peningkatan berat badan, akumulasi lemak, lemak visceral dan BMR. Indeks massa tubuh merupakan parameter yang paling banyak digunakan untuk menginterpretasikan peningkatan berat badan atau obesitas dan masih digunakan sebagai indikator penumpukan lemak tubuh [10]. Obesitas sebagai suatu kondisi tubuh yang mengalami kelebihan lemak tubuh, sehingga menyebabkan masalah kesehatan seperti penyakit diabetes, kardiovaskular, dislipidemia dan kanker [11]. Keadaan inilah yang menyebabkan dua individu dengan usia kronologis yang sama, dapat memiliki usia biologis yang berbeda. Hal ini tergantung dari risiko kesehatan masingmasing individu [12]. Peningkatan jaringan adiposa dalam tubuh obesitas menyebabkan terjadinya chronic low-grade inflammation [13], [14]. Chronic low-grade inflammation ini terjadi karena jaringan adiposa mengeluarkan substrat pro-inflamasi (interleukin-1, interleukin-6, TNF- $\alpha$ dan IFN $\gamma$ ) yang dipicu akibat adanya hipoksia jaringan adiposa yang mengalami hyperplasia progresif sehingga menurunkan suplai aliran darah ke sel adiposity [13]. Chronic lowgrade inflammation ini secara terus menerus akan mengganggu dan merusak metabolisme sel yang erat kaitannya dengan usia metabolic [13], [15].

Penelitian yang dilakukan oelh Refrensi [15] terhadap 69 subyek lakilaki dewasa yang dilakukan pemeriksaan interleukin $1 \beta$ didapatkan bahwa peningkatan jaringan adiposa tubuh dan usia metabolik berkorelasi positif dengan peningkatan parameter inflamasi (IL-1 $\beta$ ) dan risiko penyakit kardiovaskular. Hal ini sesuai dengan penelitian Refrensi [12] yang mengungkapkan bahwa usia metabolik dapat menjadi pemeriksaan informatif bagi usia biologis individu sehingga risiko kesehatan tiap individu dapat diterapi secara persona.

\section{KESIMPULAN}

Hasil penelitian ini menunjukkan bahwa adanya korelasi yang kuat antara IMT dan usia metabolik. Semakin meningkat IMT maka usia metabolik menjadi tinggi atau 
menjadi lebih tua daripada usia kronologisnya.

\section{DAFTAR PUSTAKA}

1. Nuttall FQ. Obesity, BMI and Health: A Critical Review. Nutr Res. 2015;50(3):117-28.

2. Sarnali TT, Moyenuddin P. Obesity and Disease Association: A Review. AKMMC J. 2010;1(2):21-4.

3. Levi J, Segal LM, Rayburn J, Martin A. The State of Obesity. Princeton; 2015.

4. Badan Penelitian dan Pengembangan Kesehatan Kementerian Kesehatan RI. HASIL UTAMA RISKESDAS 2018. Jakarta; 2018.

5. Pratama BF, Christianto E, Bebasari E. Korelasi Indeks Massa Tubuh dengan Tekanan Darah pada Mahasiswa Fakultas Kedokteran Universitas Riau Angkatan 2012 dan 2013. JOM FK. 2015;2(2):1-10.

6. Tchernof A, Després J-P. Pathophysiology of human visceral obesity: an update. Physiol Rev. 2013;93(1):359-404.

7. Kaziuk, Magdalena Barbara Kosiba W, Kuzniewski M. High metabolic age and excessive adipose tissue as a storage location for toxins, and their influence on the excretory function of a liver and bile duct in patients with a transplated allogenic kidney. Transpl J. 2016;S53.

8. DeLany JP. Energy Requirement Methodology. In: Nutrition in the Prevention and Treatment of Disease [Internet]. Elsevier; 2017 [cited 2019 Nov 13]. p. 85-102. Available from: https://linkinghub.elsevier.com/retriev e/pii/B9780128029282000047

9. Majzoub $\mathrm{A}$, Talib $\mathrm{R}$, Canguven $\mathrm{O}$, Elbardisi H, Arafa M, Khalafalla K, et al. Metabolic age versus chronologic age effect on the gonadal state. Fertil Steril. 2017 Sep 1;108:e46-7.

10. Metin M, Orkide. Evaluation of Obesity Degree From The Points of View of Chronological As Metabolic Ages. Vol. 7, Namık Kemal Tıp Dergisi. 2019.

11. Andersen C, Sloan A, Dupree L, Walker B. Younger Relative Metabolic Age Is Associated with a More Favorable Body Composition and Plant-based Dietary Pattern (P21038-19). Curr Dev Nutr. 2019 Jun $1 ; 3$ (Supplement_1):1871.

12. Hertel J, Friedrich $\mathrm{N}$, Wittfeld $\mathrm{K}$, Pietzner M, Budde K, Van der Auwera $S$, et al. Measuring Biological Age via Metabonomics: The Metabolic Age Score. J Proteome Res [Internet]. 2016 Feb 5 [cited 2019 Nov 13];15(2):400-10. Available from: 
https://pubs.acs.org/doi/10.1021/acs.j

proteome.5b00561

13. Ellulu MS, Patimah I, Khaza'ai $H$, Rahmat A, Abed Y. Obesity \& inflammation: The linking mechanism \& the complications. Arch Med Sci. 2017;13(4):851-63.

14. Lee H, Lee IS, Choue R. Obesity, Inflammation and Diet. Pediatr Gastroenterol Hepatol Nutr. 2013;16(3):143.

15. Garcia-Rubira JC, Cano-Garcia FJ, Bullon B, Seoane T, Villar P V., Cordero MD, et al. Body fat and metabolic age as indicators of inflammation and cardiovascular risk. Eur J Prev Cardiol. 2018;25(3):233-4. 